
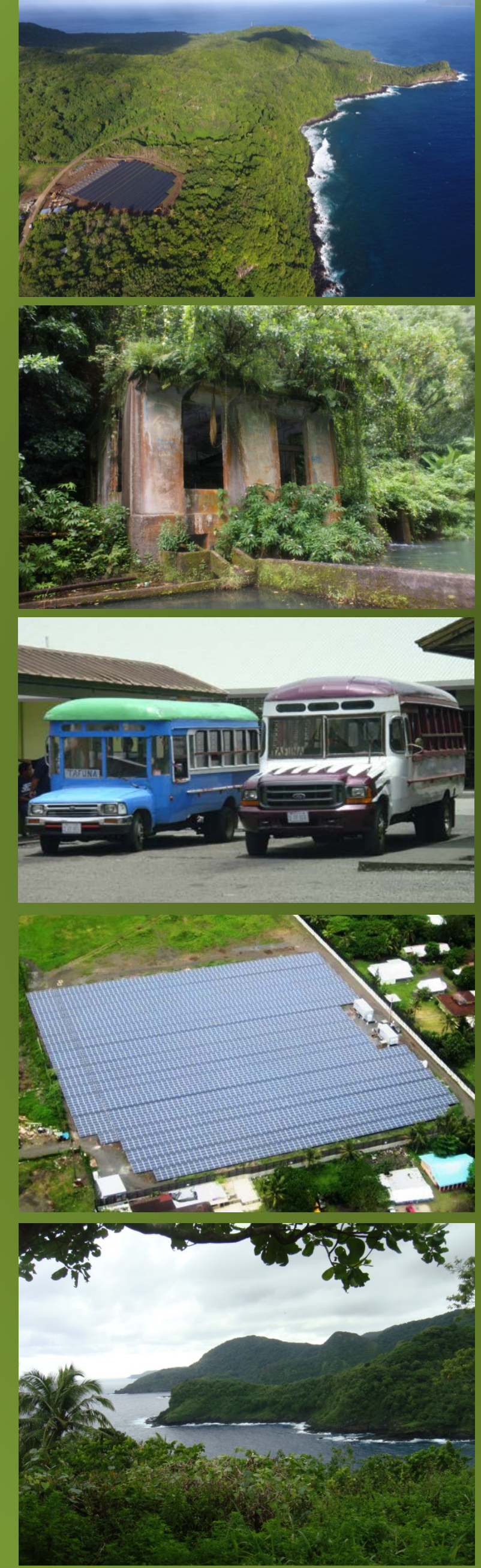

\section{American Samoa}

\section{Energy Action Plan}

J. Erik Ness, Scott Haase and Misty Conrad

Sponsored by the Department of the Interior Office of Insular Affairs

\section{September 2016}

Produced under direction of the U.S. Department of the Interior Office of Insular Affairs by the National Renewable Energy Laboratory (NREL) under Interagency Agreement IAG12-1865 and Task No. WFN91057 
This energy plan was prepared and facilitated by J. Erik Ness, Scott Haase and Misty Conrad of the National Renewable Energy Laboratory

under the guidance of the American Samoa Renewable Energy Committee

\section{ACKNOWLEDGMENTS}

The National Renewable Energy Laboratory (NREL) thanks the U.S. Department of the Interior's Office of Insular Affairs (OIA) for providing funding for this effort. In particular, NREL would like to acknowledge the valuable assistance and direction provided by OIA's Mark Brown.

NREL would also like to thank the American Samoa Renewable Energy Committee (ASREC) for their support in the development, review and finalization of this energy action planning document and the ongoing energy transformation efforts in American Samoa. ASREC members are listed in Appendix A.1.

Dan Olis and Brett Oakleaf of NREL provided review input and Judy Powers designed the cover.

\section{NOTICE}

This manuscript has been authored by employees of the Alliance for Sustainable Energy, LLC ("Alliance") under Contract No. DE-AC36-08G028308 with the U.S. Department of Energy ("DOE").

This report was prepared as an account of work sponsored by an agency of the United States government. Neither the United States government nor any agency thereof, nor any of their employees, makes any warranty, express or implied, or assumes any legal liability or responsibility for the accuracy, completeness, or usefulness of any information, apparatus, product, or process disclosed, or represents that its use would not infringe privately owned rights. Reference herein to any specific commercial product, process, or service by trade name, trademark, manufacturer, or otherwise does not necessarily constitute or imply its endorsement, recommendation, or favoring by the United States government or any agency thereof. The views and opinions of authors expressed herein do not necessarily state or reflect those of the United States government or any agency thereof. 


\section{DOCUMENT OVERVIEW}

This document outlines actions being taken to reduce American Samoa's petroleum consumption. It describes the four near-term strategies selected by the American Samoa Renewable Energy Committee (ASREC) during action-planning workshops conducted in May 2016, and describes the steps that will need to be taken to implement those strategies.

In August 2016, following the action-planning workshops, ASREC adopted a goal of having $50 \%$ of American Samoa's energy come from renewable energy resources by 2025 and $100 \%$ by 2040 . All of the strategies in this action plan support those targets.

This 2016 Energy Action Plan builds upon the 2013 American Samoa Energy Action Plan, ${ }^{1}$ provides a progress update on the 2013 priority actions (Table 1 ), and adds new priority actions (Table 2 ). This document is intended to evolve along with the advancement of the projects and will be updated to reflect progress.

Table 1. Status of 2013 American Samoa Petroleum Reduction Strategies

\begin{tabular}{|c|c|c|}
\hline STRATEGY & ACTIONS & StRATEGy DEADLINE \\
\hline $\begin{array}{l}\text { Strengthen the } \\
\text { institutional capacity of } \\
\text { ASREC }\end{array}$ & $\begin{array}{l}\text { - Hire a part time coordinator } \\
\text { - Develop proposal(s) for submission to the EIC } \\
\text { grant program }\end{array}$ & Complete \\
\hline $\begin{array}{l}\text { Make Manu'a } 100 \% \\
\text { renewable energy } \\
\text { dependent by } 2016\end{array}$ & $\begin{array}{l}\text { - Initial deployment of PV for Ofu and Ta'u } \\
\text { - Conduct initial engineering studies for a transition } \\
\text { to } 100 \% \text { renewable energy on Manu'a }\end{array}$ & $\begin{array}{l}\text { System under } \\
\text { construction }\end{array}$ \\
\hline $\begin{array}{l}\text { Wind and solar } \\
\text { deployment for Tutuila }\end{array}$ & $\begin{array}{l}\text { - Conduct prefeasibility study for grid integration } \\
\text { - Determine the viability of issuing RFPs for wind } \\
\text { and solar IPPs } \\
\text { - Issue RFP for the grid integration study }\end{array}$ & Complete \\
\hline $\begin{array}{l}\text { Assess the potential for } \\
\text { geothermal power for } \\
\text { Tutuila }\end{array}$ & $\begin{array}{l}\text { - Preliminary evaluation (Phase I) } \\
\text { - Resource confirmation (Phase II) }\end{array}$ & $\begin{array}{l}\text { Complete } \\
\text { (no commercial } \\
\text { resource } \\
\text { identified) }\end{array}$ \\
\hline $\begin{array}{l}\text { Hydroelectric power } \\
\text { resource development }\end{array}$ & $\begin{array}{l}\text { - Develop a proposal for a feasibility assessment of } \\
\text { the Fagatogo Hydroelectric Complex for } \\
\text { submission to the EIC grant program } \\
\text { - Develop an engineering design/architectural } \\
\text { design, and access and trail design proposal for } \\
\text { the next round of funding based on the results of } \\
\text { the feasibility study } \\
\text { - Develop a restoration proposal for the next round } \\
\text { of funding based on the results of the engineering } \\
\text { and architectural design work }\end{array}$ & $\begin{array}{l}\text { Carried over to } \\
2016 \text { plan as a } \\
\text { lower-priority } \\
\text { strategy (see } \\
\text { Appendix A.2) }\end{array}$ \\
\hline
\end{tabular}

${ }^{1}$ http://www.nrel.gov/docs/fy13osti/59190.pdf 
Table 2. American Samoa 2016 High-Priority Petroleum Reduction Strategies

\begin{tabular}{|l|l|l|}
\hline \multicolumn{1}{|c|}{ STRATEGY } & \multicolumn{1}{|c|}{ ACTIONS } & \multicolumn{1}{|c|}{$\begin{array}{c}\text { STRATEGY } \\
\text { DEADLINE }\end{array}$} \\
\hline $\begin{array}{l}\text { 1. Develop demand-side } \\
\text { management program }\end{array}$ & $\begin{array}{l}\text { - Quantify current energy consumption to identify } \\
\text { potential energy savings } \\
\text { - Design an implementable DSM program } \\
\text { - Execute the DSM program }\end{array}$ & $\begin{array}{l}\text { December 21, } \\
2019\end{array}$ \\
\hline 2. Develop wind power & - Develop wind power through a PPA & $\begin{array}{l}\text { December 31, } \\
2020\end{array}$ \\
\hline $\begin{array}{l}\text { 3. Develop solar power } \\
\text { 4. Reduce petroleum use } \\
\text { by land-based vehicles }\end{array}$ & $\begin{array}{l}\text { - Phase 1: Develop 10 MW PV with storage } \\
\text { Storage 2: Develop an additional 10 MW PV with }\end{array}$ & $\begin{array}{l}\text { September 30, } \\
2018\end{array}$ \\
\hline $\begin{array}{l}\text { land vehicles } \\
\text { to qualify for EV credits } \\
\text { - Implement a pilot program for ASG vehicles }\end{array}$ & January 31, \\
\hline
\end{tabular}




\section{Table of Contents}

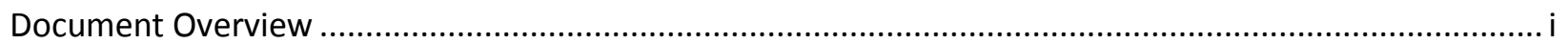

American Samoa Renewable Energy Committee ….............................................................................. 4

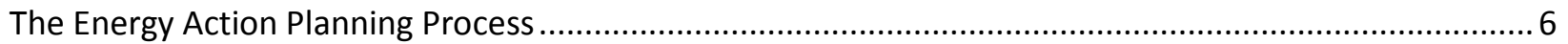

Strategy 1. Develop and Implement a Demand-Side Management Program.......................................

Action 1. Quantify current energy consumption to identify potential energy savings .......................... 8

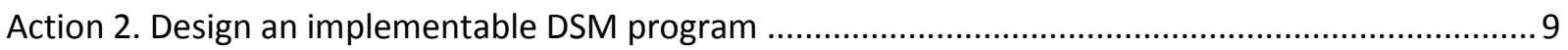

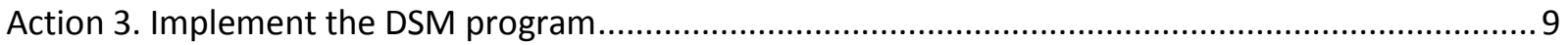

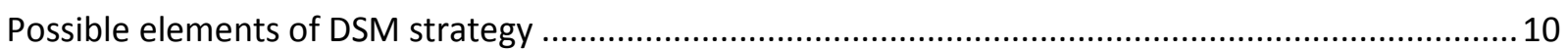

Strategy 2. Develop Wind Power on Tutuila ............................................................................... 12

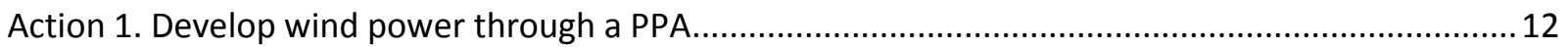

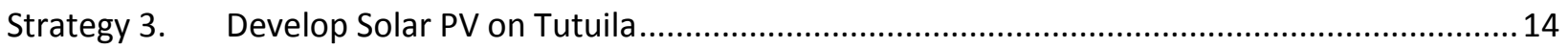

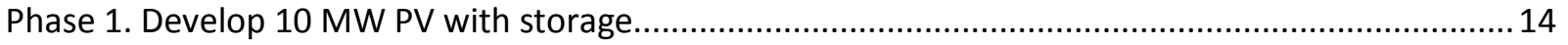

Phase 2. Develop an additional 10 MW PV with storage ............................................................... 15

Strategy 4. $\quad$ Reduce Petroleum Use by Land-Based Vehicles........................................................... 16

Action 1. Conduct a thorough transportation study for land vehicles ............................................... 16

Action 2. Explore legislative options to allow AS residents to qualify for EV credits ...........................17

Action 3. Implement a pilot program for ASG vehicles ................................................................. 17

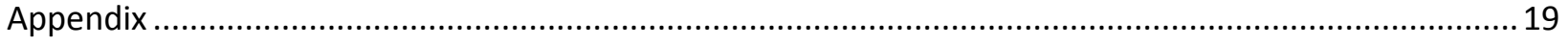

A.1. ASREC Energy Task Force Members and Other Contributors to the Action Plan.......................... 19

A.2. Support for the ASHPO Fagatogo Hydropower and Microfiltration Project ................................. 19

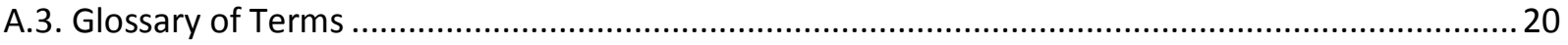

\section{Tables}

Table 1. Status of 2013 American Samoa Petroleum Reduction Strategies ............................................ i

Table 2. American Samoa 2016 High-Priority Petroleum Reduction Strategies....................................... ii 


\section{American Samoa Renewable Energy Committee}

The American Samoa Renewable Energy Committee (ASREC) was established by Executive Order 0042010 on June 7, 2010, as amended by Executive Order 009-2013 on April 18, 2013.

ASREC is a non-regulatory advisory group sponsored by the current Administration, composed of local volunteers from multi-sector stakeholder communities, and supported by federal agencies. ASREC has been meeting regularly since it first convened in November 2010.

\section{Vision}

Create a sustainable future by reducing dependence on fossil fuels.

\section{Mission}

Enhance the well-being of our citizenry, ensure energy and economic security through energy independence and diversification, and improve environmental quality. Educate all stakeholders on the importance of our vision by embracing conservation, energy efficiency and alternative energy. ASREC is a forum for considering options and offering guidance related to the achievement of its energy goals through policy, projects and programs.

ASREC's mission includes the following objectives:

1. Reduction of reliance and expenditures on petroleum fuels

2. Development of indigenous and renewable energy sources

3. Improvement of energy generation infrastructure

4. Resource preservation, restoration and enhancement

5. Training and education regarding energy efficiency and conservation

6. Development of funding and financial strategies for sustainability and economic development

7. Engagement in national and regional efforts to address island energy concerns

8. Support energy literacy curriculum in all educational institutions

9. Develop a vision, mission and goals for reducing dependence on fossil fuels, improving energy efficiency, and developing renewable energy resources

10. Establish an organizational structure to appropriately develop a comprehensive, long-term Strategic Energy Plan for American Samoa

11. Work with territorial and federal officials to secure technical assistance in the form of expertise and funding in order to move the Committee's mission forward 
In addition to the above, in May 2016, ASREC added the following objectives to its mission:

- Continue to research and explore nascent alternative energy production and energy management and storage technologies. Solicit open technology IPP RFPs as necessary to implement future new but demonstrated power generation and storage alternatives. This objective includes a more comprehensive investigation of the use of batteries at Tafuna and Satala generation sites. The purpose of such a project would be to: a) allow for greater RE penetration into the grid, b) allow for energy storage at low energy consumption hours, to be distributed during peak hours, and c) be used as backup power during temporary, unexpected/planned shut-downs.

- $\quad$ ASREC also intends to fully support the American Samoa Historic Preservation Office (ASHPO) in their efforts to fund, design and undergo restoration of the Fagatogo Hydroelectric and Microfiltration Project. (Appendix A.2)

- Investigate the potential of ocean thermal energy conversion (OTEC) technologies, already under way (no actions).

- Investigate waste-to-energy options, already under way (no actions).

\section{Directive}

Due to fluctuating energy prices and natural disasters such as the September 2009 earthquake and tsunami, American Samoa has focused attention on the need to develop alternatives to its near $100 \%$ reliance on petroleum by implementing energy efficiency and renewable energy technologies. ASREC is undertaking a concerted effort to address current energy and environmental challenges. Due to American Samoa's geographic isolation, non-renewable resources are extremely limited and subject to volatility in pricing and availability. Energy security is fundamental to American Samoa's economic future and quality of living. Consequently, creating a stable investment atmosphere remains challenging, while the quality of life for residents and visitors continues to be affected.

American Samoa's indigenous resources are abundant and should be considered to achieve energy diversity. Through appropriate study and discussion, ASREC will determine cost effective alternatives that will successfully support the committee's vision. 


\section{The Energy Action Planning Process}

In the summer of 2010, the U.S. Department of the Interior (DOI) Office of Insular Affairs (OIA) funded the National Renewable Energy Laboratory (NREL) to conduct an initial technical assessment for American Samoa. The American Samoa Initial Technical Assessment Report ${ }^{2}$ was published in 2011, and was used by ASREC to complete the American Samoa Energy Strategies ${ }^{3}$ document.

In May 2013, ASREC conducted energy action planning workshops, with support from NREL staff, to identify the near-term strategies that would be likely to have the greatest impact on reducing American Samoa's petroleum fuel energy consumption.

Unlike the Strategic Energy Plan, which established the overall long-term goals for energy consumption and generation in American Samoa, the 2013 Energy Action Plan ${ }^{4}$ selected a handful of specific strategies that were achievable in the short term (1-3 years), detailed the strategies in feasible incremental steps, identified the stakeholders and desired outcomes, identified the organizations and individuals responsible for implementing the actions, and established a timeline for each step. The 2013 action plan was envisioned as a living document that would be regularly updated by the task force.

In early 2016, ASREC requested support from OIA and NREL to develop an update to the 2013 plan. This document is the 2016 American Samoa Energy Action Plan. In May 2016, staff from NREL traveled to American Samoa for four days of energy planning meetings. In addition to NREL, these meetings were attended by members of ASREC, the American Samoa Power Authority (ASPA), the Territorial Energy Office (TEO), and the Department of Public Works (DPW). The actions resulting from those planning sessions are described in detail in this document.

As was the case in 2013, ASREC focused on mature, proven technologies that are commercially available and financially viable today. Care was taken to ensure that the actions selected were not duplicating existing efforts, and that they leveraged work in other agencies and organizations as much as possible. The 2016 update added new strategies addressing demand-side management (DSM) and transportation issues. Progress toward each strategy is being monitored by TEO and ASPA.

\footnotetext{
${ }^{2}$ http://www.nrel.gov/docs/fy11osti/50905.pdf

${ }^{3}$ http://www.nrel.gov/docs/fy14osti/60556.pdf

${ }^{4}$ http://www.nrel.gov/docs/fy13osti/59190.pdf
} 


\section{Strategy 1. Develop and Implement a Demand-Side Management PROGRAM}

During the action planning workshops, ASREC established that there would be a benefit to reducing the overall demand for electricity in American Samoa. This strategy is in line with ASREC's goal of reducing fossil fuel imports to the Territory. A DSM program can help to accomplish this goal.

DSM refers to actions undertaken by a utility to change the level or timing of energy use on the customer side of the electricity meter, generally with the intention of optimizing existing and planned generation and transmission assets on the utility side of the meter. This is in contrast to "supply-side" strategies, which increase energy supplies (by building new power plants, for example) or increasing efficiencies at the power plant. DSM encompasses utility-initiated actions to improve energy efficiency, increase energy conservation, and reduce peak electricity demand. Examples include rebates, incentives and utility investments that improve building shell insulation and the efficiency of heating and cooling systems, and rate structures that shift demand from times of peak energy use to off-peak hours.

DSM includes other load management approaches, such as direct load control systems that enable the grid operator to regulate the electricity used by individual appliances or equipment on customer premises (usually residences), and contractual arrangements that allow the utility to reduce demand by specific customers (usually businesses) through direct action by the grid operator (remote control including cycling equipment on/off) or by the customer voluntarily taking action to reduce demand when requested by the grid operator.

The primary goal of DSM measures is to smooth out the daily peaks and valleys in energy demand to make the most efficient use of energy resources and to avoid or postpone the construction of new generating plants. Such measures represent the "low-hanging fruit" when evaluating energy strategies, as it is typically cheaper and quicker to reduce the demand for grid electricity than to add new utility generation. Demand-side resources such as energy storage systems can also help to integrate higher levels of intermittent renewable generation on the grid.

During the planning sessions, ASREC identified potential elements of a DSM program focusing on the following strategies, although additional approaches may be used once all options have been evaluated.

- Energy efficiency - The process of using less energy to provide the same service, or using the same amount of energy to provide more services. Energy efficiency typically requires the use of a different energy technology or using existing technology in a different way. For example, a compact fluorescent light (CFL) or light-emitting diode (LED) bulb is more energy efficient than a traditional tungsten incandescent light bulb because it produces the same amount of light (measured in lumens) using significantly less electrical energy.

- Energy conservation - The process of using less energy by reducing or going without a service. Energy conservation typically requires a change in behavior or not using an existing technology, e.g., turning off a light, using the stairs instead of taking the elevator, or turning up the thermostat on an air conditioner. Popular approaches to accomplishing energy conservation goals include (1) 
educating people about how to conserve energy and (2) implementing non-energy-consuming technologies such as cool roofs, which reduce the need for air conditioning.

OVERALL GOAL: Reduce peak electricity demand (or demand per capita) for ASPA as a whole by $10 \%$ compared to 2015 peak demand.

Target (a) the major energy users groups and (b) the major energy-using systems during the next three years.

OVERALL RESPONSIBILITY: TEO (Aliitama Sotoa)

POTENTIAL CHALLENGES:

- Appropriations

OVERALL DEADLINE: $\quad$ December 21, 2019

Action 1. Quantify current energy consumption to identify potential energy savings

The purpose of this action is to identify target customers and potential technology options for a DSM program. This action includes quantifying energy consumption by:

1. The largest user groups: probably the American Samoa Government (ASG), the canneries, and the Department of Education.

2. The major energy-consuming technologies: probably air conditioning and lighting, including street lights.

Goal: Identify the most cost effective elements for program implementation.

Responsible for coordinating implementation: TEO

Specific steps and timeline:

1. Identify (a) the major energy users groups and (b) the major energy-using systems

This step involves gathering data on customer loads and conducting end use studies.

Responsible: Joachim Fong

Due date: $\quad$ September 30, 2016

Potential challenges: Lack of available audit data and load profiles of customers

Step funding needs: None

2. Analyze data, rank by consumption, and select the priority target users and systems

Responsible: $\quad$ ASPA and TEO

Due date: $\quad$ November 30, 2016

Step funding needs: None

Reporting on progress and measuring impact: Progress reporting will be carried out by TEO and reviewed by ASREC. 
Estimated action funding: None

\section{Action 2. Design an implementable DSM program}

Goal: Develop the DSM program and identify program funding needs.

Responsible for coordinating implementation: TEO

Specific steps and timeline:

\section{Initial program design}

This will involve conducting research on the elements of successful program design, investigating possible technology options (e.g. solar air conditioners and adsorption chillers) and establishing suitable metrics for measuring impact (e.g. how California utilities measure progress toward California's $20 \%$ energy efficiency target).

Responsible: $\quad$ Aliitama Sotoa

Due date: $\quad$ February 28, 2017

Potential challenges: $\quad$ 1. Availability of staff

2. Availability of funding - could determine which options are pursued

External roles: $\quad$ Possibly use a consultant to provide input on DSM program design.

Step funding needs: May be required if consultant is used.

2. Identify program funding requirements

Responsible: Aliitama Sotoa

Due date: $\quad$ March 31, 2017

Step funding needs: None

Reporting on progress and measuring impact: Via ASREC general meetings.

Estimated action funding: $\quad$ Uncertain, to be determined as part of step 1.

\section{Action 3. Implement the DSM program}

Goal: Reduce power demand throughout the Territory.

Responsible for coordinating implementation: TEO

Specific steps and timeline:

The activities below represent the broad steps required for implementation. Detailed steps, activities, responsibilities and due dates will be determined following completion of the above two actions.

1. Identify the amount of funding that will be needed to implement the program

Responsible: $\quad$ TEO (and ASPA for street lights)

Due date: $\quad$ March 31, 2017 
Step funding needs: None

2. Implement the DSM program

Responsible: $\quad$ ASPA and TEO

Due date: $\quad$ TBD based on the outcome of the previous step

Potential challenges: 1 . Availability of staff

2. Availability of funding for the DSM program

Step funding needs: None

Reporting on progress and measuring impact: Progress reporting will be carried out by TEO and reviewed by ASREC.

Estimated action funding: This is to be determined as part of step 1.

Possible elements of DSM strategy

These elements relate to action 2, step 1.

\section{Switch CFLs to LEDs in ASG offices}

Potential challenges: 1. Financial restrictions (insufficient appropriations)

2. Issues related to CFL disposal/recycling

Note: CFLs (both partially spent and burned-out) are currently being stored for future disposal.

2. Switch CFLs to LEDs at Dept. of Education offices and in schools

Responsible: $\quad$ TEO (and ASPA for street lights)

\section{LIHEAP, WAP, Energy-efficient appliances}

Establish a minimum standard for air conditioners, e.g. SEER $15+$.

\section{Switch high-pressure sodium street lights to LEDs}

Goal: $\quad$ Reduce energy consumption and street light maintenance costs (LEDs need to be replaced less often)

Current status: $\quad$ Most street lights are currently high-pressure sodium lamps ( $275 \mathrm{~W}$ each).

ASPA installed 40 LED street lights as a test (60-75 W each).

Tasks: $\quad$ Consider light pollution aspects.

Evaluate performance contracting for street lights.

For reference: $\quad$ CNMI has approximately 2000 street lights

American Samoa has approximately 5600 street lights. 
Note: There are no legal aspects to consider; American Samoa does not have light pollution laws.

\section{Eliminate personal use of ovens in schools}

Ovens are often used by individuals after school hours.

6. Introduce legislation to prevent non-Energy-Star-compliant equipment entering American Samoa

Current status: $\quad$ American Samoa follows the US mainland Energy Star standards.

Tasks: $\quad$ Compliance testing will be required.

7. Water heaters - solar or heat pumps

8. Evaluate solar air conditioning / adsorption chillers

9. Identify the amount of funding that will be needed to implement the program

Goal: $\quad$ Reduce electricity waste and photocell maintenance/replacement costs. 


\section{Strategy 2. Develop Wind Power on Tutuila}

Wind energy is a potentially attractive option for American Samoa. ASPA has already started exploring development options and has received a proposal for a wind power purchase agreement (PPA) that will include one year of meteorological monitoring. This proposal is the primary focus of the wind strategy.

OVERALL GOAL: The goal of this strategy is to increase the total amount of wind energy deployed on Tutuila to as much as $12 \mathrm{MW}$, which directly helps ASREC reach its target of having $50 \%$ of American Samoa's energy come from renewable energy resources by 2025 and 100\% by 2040 .

OVERALL RESPONSIBILITY: ASPA

POTENTIAL CHALLENGES:

- Environmental permitting, including avian issues

- Land availability and negotiation of land lease prices - however ASPA has already secured land rights for one parcel

- Issues related to system integration and grid stability - vendor responsibility

- Availability of cranes for turbine installation - vendor responsibility

- Running a subtransmission line from the identified wind site to the main electric grid - vendor responsibility

- Availability (or construction costs) of suitable access roads - vendor responsibility; Public Works charges approximately $\$ 1$ million per mile for a 20 -wide road

OVERALL DEADLINE: December 31, 2020

\section{Action 1. Develop wind power through a PPA}

Goal: Implement wind power development on Tutuila at less than 10 cents/kWh.

Responsible for coordinating implementation: ASPA

\section{Specific steps and timeline:}

\section{ASPA review vendor proposal and negotiate best and final offer}

Require vendor to add pyranometers to the met towers to gather solar insolation data concurrently with wind data.

Responsible: ASPA

Due date: $\quad$ November 1, 2016

2. Final go/no-go decision by ASPA Board of Directors

Responsible: ASPA

Due date: January 30, 2017

\section{Sign PPA and issue notice to proceed}


Responsible: $\quad$ ASPA

Due date: $\quad$ April 30, 2017

4. Obtain the required permits to install met tower(s)

Responsible: $\quad$ TBD

Due date: $\quad$ FAA permits: May 30, 2017

WS permits: December 31, 2017

5. Issue notice to proceed with installing monitoring towers

Responsible: $\quad$ ASPA

Due date: January 1, 2018

6. Vendor to evaluate wind resource for one year

Responsible: Vendor

Due date: $\quad$ August 31, 2018

7. Vendor to obtain final permits and approvals

Responsible: Vendor

Due date: $\quad$ August 31, 2019

8. Construction and commercial operation

Responsible: $\quad$ To be determined

Due date: $\quad$ December 31, 2020

Reporting on progress and measuring impact: ASPA project engineer TBD.

Estimated action funding: None (staff time is covered by ASPA, development costs are covered by the vendor) 


\section{Strategy 3. DeVelop Solar PV on Tutuila}

Solar photovoltaics (PV) represents the best-available option for significantly expanding the percentage of electricity generated from renewable resources over the near term. Project lead times are much shorter than for wind power systems. The success of previous solar installations in American Samoa is encouraging and has set a positive precedent for further development of solar power generation. Incorporating energy storage into PV installations increases their value substantially, allowing solargenerated electricity to be consumed during evening peak hours and producing various ancillary services for the grid. The overall target for this strategy is to add an additional $20 \mathrm{MW}$ of PV generation on Tutuila in two phases. The ASPA Board of Directors has already approved phase 1.

OVERALL GOAL: Construct up to $20 \mathrm{MW}$ of solar PV incorporating energy storage in two phases; $10 \mathrm{MW}$ each. This helps ASREC reach its target of having 50\% of American Samoa's energy come from renewable energy resources by 2025 and $100 \%$ by 2040 .

OVERALL RESPONSIBILITY: ASPA

\section{POTENTIAL CHALLENGES:}

- Permitting

- Land availability and negotiation of land lease prices - ASPA is currently negotiating land leases for phase 1 and has identified suitable parcels for phase 2 and is currently seeking development permission from the landowners

- Issues related to system integration and grid stability

OVERALL DEADLINE: September 30, 2018

Phase 1. Develop 10 MW PV with storage

Responsible for coordinating implementation: ASPA

Specific steps and timeline:

Add a grid integration study possibly covering both phase 1 and phase 2 .

\section{Finalize land leases for Phase 1}

Responsible: $\quad$ ASPA

Due date: $\quad$ September 30, 2016

\section{Final system design}

Responsible: ASPA

Due date: December 31, 2016

3. Mobilize and begin construction

Responsible: ASPA

Due date: $\quad$ April 30, 2017 
4. Commercial online date (COD)

Responsible: $\quad$ ASPA

Due date: $\quad$ November 30, 2017

Reporting on progress and measuring impact: ASPA project engineer TBD.

Estimated action funding: This is to be determined as part of steps 1 and 2 .

Phase 2. Develop an additional $10 \mathrm{MW}$ PV with storage

Individual steps for this phase are timed so that construction of the systems under phase 2 start after construction of phase 1 systems is complete.

Responsible for coordinating implementation: ASPA

Specific steps and timeline:

1. Obtain final approval from ASPA Board of Directors for Phase 2

Responsible: ASPA

Due date: June 1, 2017

2. Finalize land leases for Phase 2

Responsible: ASPA

Due date: $\quad$ December 31, 2017

3. Final system design

Responsible: ASPA

Due date: July 31, 2017

4. Mobilize and begin construction

Responsible: ASPA

Due date: $\quad$ September 30, 2017

5 Commercial online date (COD)

Responsible: ASPA

Due date: $\quad$ September 30, 2018

Reporting on progress and measuring impact: ASPA project engineer TBD.

Estimated action funding: This is to be determined as part of steps 2 and 3 . 


\section{Strategy 4. Reduce Petroleum Use by Land-Based Vehicles}

The nearly 9000 road vehicles in American Samoa consume approximately 6 million gallons of petroleum fuel annually. Roughly $5 \%$ of these vehicles are owned by the American Samoa Government (ASG). A study by Westmoreland in 2012 found that the average fuel efficiency of vehicles in the Territory was in the range of 13-15 mpg. Given the high cost of imported fuel, during the May 2016 action planning sessions ASREC decided to investigate options for stimulating adoption of electric vehicles (EVS) and hybrid electric vehicles (HEVs) in American Samoa.

OVERALL GOAL: Develop a land-based petroleum reduction strategy and implement a pilot project.

OVERALL RESPONSIBILITY: TEO and DPW POTENTIAL CHALLENGES:

- Infrastructure: absence of EV/HEV dealerships with mechanics qualified to service the vehicles

- Infrastructure: lack of EV charging stations

- Financial: lack of funding for infrastructure and O\&M capacity development

- Financial: higher up-front costs of EVs/HEVs

- Financial: American Samoans do not qualify for federal EV/HEV tax credits

- Cultural: Local preference is for larger vehicles

OVERALL DEADLINE: January 31, 2019

\section{Action 1. Conduct a thorough transportation study for land vehicles}

This action will update the 2012 Westmoreland study, to include:

- Number of vehicles by type (compacts, sedans, light and heavy duty trucks, etc.)

- Average miles per week traveled in various sectors (ASG, commercial, private, etc.)

- Analysis of the emissions- and fuel-consumption-reduction benefits of road improvements, such as filling in potholes and using roundabouts at traffic intersections instead of traffic lights

- The potential value of using EV batteries for load leveling, including the benefit of increased resiliency to disasters

- The rate of attrition of ASG vehicles, which could then be replaced with EVS or HEVs

- Incentives that would encourage private vehicle owners to purchase EVs or HEVs

- Input from car dealerships regarding their interest in stocking EVs and HEVs

Responsible for coordinating implementation: TEO and DPW 
Specific steps and timeline:

1. Identify potential funding sources and consultant (to be used in step 2)

$$
\begin{array}{ll}
\text { Responsible: } & \text { ASREC, TEO and DPW } \\
\text { Due date: } & \text { September 1, } 2016
\end{array}
$$

2. Conduct detailed transportation study

$\begin{array}{ll}\text { Responsible: } & \text { ASREC, TEO } \\ \text { External roles: } & \text { Consultant to conduct the transportation study } \\ \text { Due date: } & \text { June } 31,2017\end{array}$

Reporting on progress and measuring impact: Once the transportation study is complete, ASREC will convene to discuss the findings and possible follow-on actions.

Estimated action funding: $\quad$ \$100K $-\$ 150 \mathrm{~K}$

Action 2. Explore legislative options to allow AS residents to qualify for EV credits

Responsible for coordinating implementation: ASREC, TEO

Specific steps and timeline:

1. Request the Governor's Office to co-write with ASREC a petition to the American Samoa Congressman's office to assist in the creation of legislation to include American Samoa in all federal incentive schemes for EVs, hybrids and charging stations.

Responsible: $\quad$ ASREC

Due date: $\quad$ March 31, 2017

Reporting on progress and measuring impact: Via ASREC general meetings.

Estimated action funding: None

Action 3. Implement a pilot program for ASG vehicles

Goal: ASG (ASPA, TEO, DPW, ASEPA) to obtain 30 electric vehicles by December 31, 2018

Responsible for coordinating implementation: TEO, DPW, ASREC

Specific steps and timeline:

1. Identify funding for procurement of electric vehicles

This could for example include applying grant funding that already covers vehicle purchases to the purchase of EVs instead of internal combustion vehicles.

Responsible: $\quad$ ASREC with cooperation from all ASG departments

Due date: July 31, 2017 
2. Install charging stations at ASPA, TEO and DPW sites

$\begin{array}{ll}\text { Responsible: } & \text { ASPA, DPW } \\ \text { Due date: } & \text { July 31, } 2017\end{array}$

3. Identify a supplier for home-based fast-charging systems

$\begin{array}{ll}\text { Responsible: } & \text { ASPA } \\ \text { Due date: } & \text { July 31, } 2017\end{array}$

Reporting on progress and measuring impact: Via ASREC general meetings.

Estimated action funding: $\quad \$ 500 \mathrm{~K}$ 


\section{APPENDIX}

\section{A.1. ASREC Energy Task Force Members and Other Contributors to the Action Plan}

- ASREC Co-Chair: Aliitama Sotoa, representing the Territorial Energy Office

- ASREC Co-Chair: Utu Abe Malae, representing the American Samoa Power Authority

- David Herdich, ASREC Secretary

- Tim Bodell, ASREC

- Mark Kneubuhl, ASREC

- Lee Slater, ASREC

- Ameko Pato, ASREC

- Wallon Young, ASPA Power Chief, ASREC Technical Advisor

- Joachim Fong, ASPA engineer, ASREC Technical Advisor

- Niu Hopkinson, representing the Territorial Energy Office

- Faalavai Taase, representing the American Samoa Department of Public Works

\section{A.2. Support for the ASHPO Fagatogo Hydropower and Microfiltration Project}

ASREC supports the ASHPO in their proposal to conduct an assessment of the Fagatogo Hydroelectric Complex and, if feasible, an engineering and architectural design for restoration work thereof. The ASHPO Director will be responsible for implementation.

The scope of work for this proposal will include the following:

- Draining and dredging of the existing reservoirs to allow for a thorough engineering assessment.

- Restoration of the existing access trail to provide safe access to the pipelines and reservoir sites for the assessment, for draining and dredging work, for potential restoration work, for educational site visits, and for economic development through heritage tourism.

- Assessment of the integrity of two existing reservoirs (if a potential third reservoir is discovered it will be added to the scope).

- Assessment of the existing cast iron pipeline.

- Assessment of the existing hydroelectric plant building.

- Assessment of using the power produced as base-load and back-up power for the ASPA water filtration plant and/or ASPA wells.

- Assessment of the potential of using the upper reservoir(s) for power storage.

- A cost benefit analysis of the total proposed hydroelectric plant restoration project effort based on potential capacity $(\mathrm{kW})$ that can be realized and energy $(\mathrm{kWh})$ over a complete seasonal cycle 
and potential fuel savings to ASPA. The analysis will also take into account potential economic benefits the site will have for heritage tourism and potential savings of using the hydroelectric plant as base-load and back-up power for the ASPA water filtration plant and/or ASPA wells.

- $100 \%$ engineering and architectural plans and cost estimates for restoration of the complex.

- A video documentary of the work done on this project for educational and heritage tourism promotion purposes.

\begin{tabular}{|c|c|}
\hline AS & American Samoa \\
\hline ASEPA & American Samoa Environmental Protection Agency \\
\hline ASG & American Samoa Government \\
\hline ASHPO & American Samoa Historic Preservation Office \\
\hline ASPA & American Samoa Power Authority \\
\hline ASREC & American Samoa Renewable Energy Committee \\
\hline CFL & compact fluorescent lamp \\
\hline CNMI & Commonwealth of the Northern Marianas \\
\hline DOI & U.S. Department of Interior \\
\hline DPW & American Samoa Department of Public Works \\
\hline DSM & demand-side management \\
\hline EE & energy efficiency \\
\hline EV & electric vehicle \\
\hline HEV & hybrid electric vehicle \\
\hline IPP & independent power producer \\
\hline kW & kilowatt \\
\hline kWh & kilowatt-hour \\
\hline LED & light-emitting diode \\
\hline MW & megawatt \\
\hline O\&M & operations and maintenance \\
\hline OIA & Office of Insular Affairs \\
\hline OTEC & ocean thermal energy conversion \\
\hline PPA & power purchase agreement \\
\hline PV & photovoltaics \\
\hline
\end{tabular}




$\begin{array}{ll}\text { RFP } & \text { request for proposal } \\ \text { SEER } & \text { seasonal energy efficiency ratio } \\ \text { TBD } & \text { to be determined } \\ \text { TEO } & \text { Territorial Energy Office } \\ \text { W } & \text { watt }\end{array}$

\section{PHOTO CREDITS}

Front cover (top to bottom): Mark Kneubuhl, American Samoa Historic Preservation Office, Misty Conrad, PIX 23033, Misty Conrad Back cover (left to right): PIX 17613, PIX 16694, PIX 10891, PIX 08022, Judy Powers. 


\section{NATIONAL RENEWABLE ENERGY LABORATORY — LEADING CLEAN ENERGY INNOVATION}

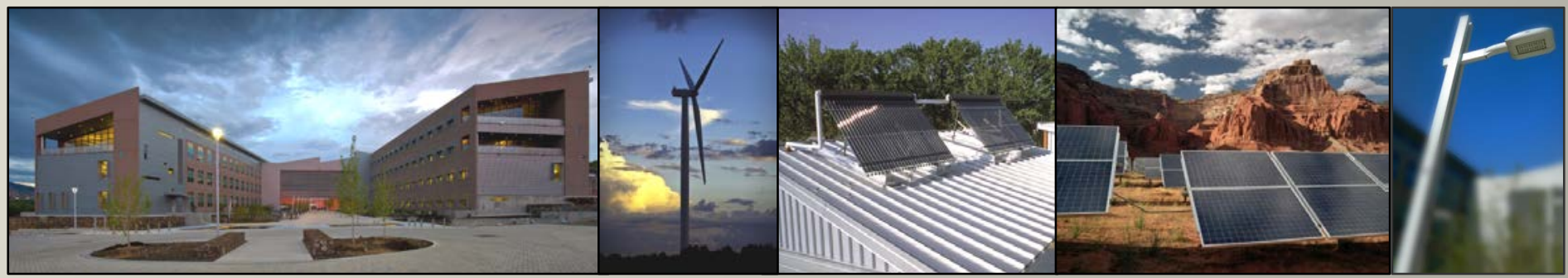

Prepared by the National Renewable Energy Laboratory (NREL), a national laboratory of the U.S. Department of Energy, Office of Energy Efficiency and Renewable Energy, operated by the Alliance for Sustainable Energy, LLC. NREL is the U.S. Department of Energy's primary laboratory for renewable energy and energy efficiency research and development.

15013 Denver West Parkway, Golden, CO $80401+303-275-3000 \bullet$ www.nrel.gov 